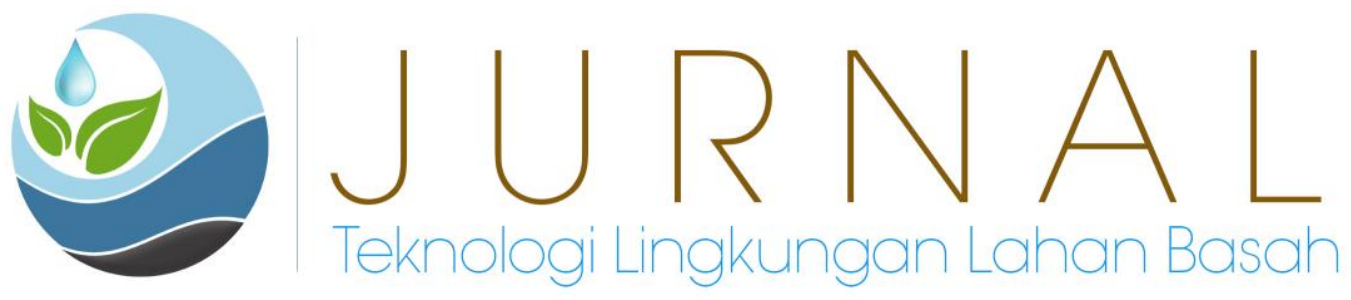

\title{
Kosentrasi BOD, Minyak dan Lemak di Permukiman Desa Bakau Besar Laut Kecamatan Sungai Pinyuh Kabupaten Mempawah
}

\author{
Isna Apriani ${ }^{1}$, Zairin Zain ${ }^{2}$, Ria Risti Astanti ${ }^{3}$ \\ ${ }^{1}$ Program Studi Teknik Lingkungan, Universitas Tanjungpura \\ ${ }^{2}$ Program Studi Teknik Arsitektur, Universitas Tanjungpura \\ ${ }^{3}$ Program Studi Teknik Sipil, Universitas Tanjungpura \\ isna.apriani@yahoo.co.id
}

\begin{abstract}
The settlements in RW 3 and RW 4 of Bakau Besar Laut village, Sungai Pinyuh district, covers an area adjacent to two small industries, namely a shrimp farm and copra processing with no WWTP facility, generating domestic wastes that potentially pollute local settlements and farms. This research has the purpose of identifying the BOD, Grease and Fat contents in the settlement by testing the drainage water quality in the local settlements and farms. Grab Sampling method was used to sample the water, whereas Mann Whitney method served in statistical test. Result of analysis shows that BOD concentration in each drainage has surpassed the quality standard specified in Government Regulation (PP) no. 82 of 2001, but the Oil and Fat concentration did not surpass the same regulation. Based on the results of Mann whitney statistica test, it was found that the BOD, Grease and Fat content has a radius of $700 \mathrm{~m}>1700 \mathrm{~m}$ (agricultural drainage) with sig value of $0.677>0.05 ; 500 \mathrm{~m}>1500 \mathrm{~m}$ (inhabitants' drainage) with sig value of $0.936>0.05$. Recommendations include clean water treatment (PAM/drinking water company) with intake from Bakau Besar Laut river and garbage sorting based on their characteristics (e.g. organic, anorganic and toxic and hazardous), establishing WWTP (Waste Water Treatment Plant) for shrimp farms and copra processing industries as well as establishing animal waste-based Biogas processing plants as sources for fuel and compost fertilizers that can be reutilized by the people.
\end{abstract}

Keywords: Pollution level, Settlement, Grab Sampling

\begin{abstract}
Abstrak
Permukiman di RW 3 dan RW 4 Desa Bakau Besar Laut,Kec. Sungai Pinyuh, merupakan kawasan yang berdekatan dengan dua industri kecil yaitu tambak udang dan pengolahan kopra yang tidak memiliki [IPAL] dengan limbah domestik yang berpotensi mencemari permukiman dan pertanian di kawasan tersebut.Riset ini bertujuan untuk mengetahui kadar BOD, Minyak dan Lemak di permukiman dengan menguji kualitas air drainase warga dan pertanian. Metode Grab Sampling digunakan untuk pengambilan sampel air dan metode Mann Whitney sebagai pengujian statistik. Hasil analisis menunjukkan bahwa_Konsentrasi BOD pada masing - masing drainase telah melewati standar baku mutu PP 82 tahun 2001 sedangkan konsentrasi Minyak dan Lemak tidak melewati standar baku mutu PP 82 tahun 2001. Berdasarkan hasil uji statistik Mann whitney didapatkan kadar BOD, Minyak dan Lemak diantaranya radius $700 \mathrm{~m}>1700 \mathrm{~m}$ (drainase pertanian) dengan nilai sig 0,677>0,05; $500 \mathrm{~m}>1500 \mathrm{~m}$ (drainase warga) dengan nilai sig 0,936>0,05. Rekomendasi berupa pengolahan air bersih (PAM) dengan intake yang berasal dari sungai Bakau Besar Laut, melakukan pemisahan sampah sesuai dengan karakteristik limbahnya yaitu organik, anorganik dan B3, mendirikan IPAL (Instalasi Pengolahan Air Limbah) untuk industri tambak udang dan pengolahan kopra serta mendirikan pengolahan Biogas berbahan baku limbah ternak sebagai sumber bahan bakar dan pupuk kompos organik yang dapat dimanfaatkan kembali oleh masyarakat.
\end{abstract}

Kata kunci: Kadar pencemaran, Permukiman, Grab Sampling 

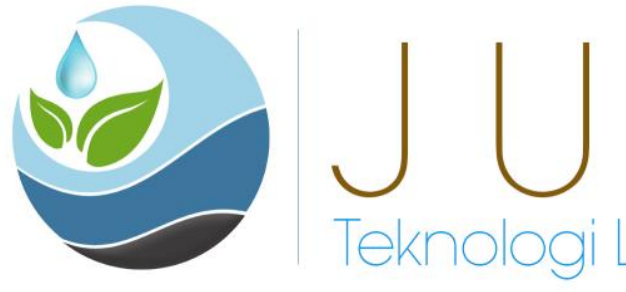

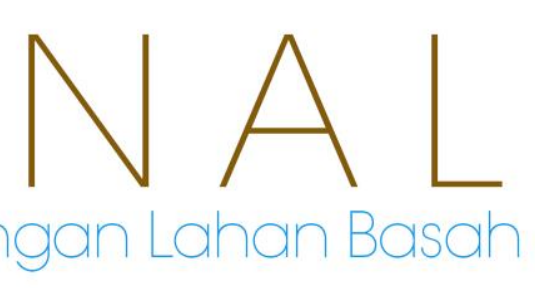

\section{PENDAHULUAN}

Hampir seluruh kegiatan yang dilakukan manusia membutuhkan air, mulai dari membersihkan diri, membersihkan tempat tinggal, menyiapkan makanan dan minuman sampai dengan aktivitasaktivitas lainnya (Achmad, 2004). Sepanjang sejarah, kualitas dan kuantitas serta kontinuitas air yang sesuai dengan kebutuhan manusia merupakan faktor penting yang menentukan kesehatan hidupnya. Kualitas air tersebut dipengaruhi oleh keberadaan berbagai jenis mikroorganisme patogen dan kandungan bahan kimia berbahaya di dalam. Menurut Palar (2008), pencemaran adalah suatu kondisi yang telah berubah dari kondisi asal ke kondisi yang lebih buruk sebagai akibat bahan - bahan pencemar atau polutan. Suatu lingkungan dikatakan tercemar apabila telah terjadi perubahanperubahan dalam tatanan lingkungan sehingga tidak sama lagi dengan bentuk asalnya, sebagai akibat masuk dan atau dimasukkannya suatu zat atau benda asing ke dalam tatanan lingkungan. Perubahan ini memberikan pengaruh (dampak) buruk terhadap organisme yang telah ada dan hidup baik dalam tatanan tersebut. Pada tingkat lanjut, perubahan ini juga dapat membunuh bahkan menghapuskan satu atau lebih organisme. Air yang telah tercemar dapat mengakibatkan kerugian yang besar bagi manusia. Kerugian ini dapat berupa air menjadi tidak bermanfaat lagi untuk keperluan rumah tangga, industri dan pertanian. Namun, kondisi di Indonesia pada umumnya memiliki permasalahan permukiman yang cukup memprihatinkan. Salah satu permukiman kampung laut RW 3 dan RW 4 yang berada di Desa Bakau Besar Laut Kecamatan Sungai Pinyuh juga mengalami kondisi serupa. Lokasi permukiman ini sangat berdekatan dengan 2 buah industri kecil yaitu tambak udang dan kopra serta beberapa aktivitas lainnya yang berpotensi menjadi faktor pencemar untuk lahan pertanian dan sumber air masyarakat. Permasalahan yang timbul adalah terdapat infrastruktur tambak udang milik perusahaan setempat yang melakukan pembuangan air limbah secara langsung ke saluran air. Jika kegiatan ini dilakukan secara terus menerus dapat menimbulkan dampak pada lingkungan permukiman, khususnya terhadap kualitas air drainase di Desa Bakau Besar Laut. Penelitian ini merupakan kelanjutan penelitian yang dilakukan oleh Astanti (2014) mengenai pengaruh penambahan probiotik terhadap buangan budidaya udang tambak. Penelitian tersebut bertujuan untuk mengetahui kualitas air buangan tambak yang telah ditambahkan probiotik oleh perusahaan lokal ke saluran air yang dekat dengan permukiman. Dari penelitian ini diperoleh temuan bahwa perusahaan tambak udang tersebut tidak mempunyai IPAL [Instalasi Pengolahan Air Limbah], air buangan melebihi standar baku mutu lingkungan PP 82 tahun 2001. Menurut pernyataannya, strategi ini mampu mengurangi beban pencemar buangan dari tambak udang dan aman untuk langsung di buang ke saluran lingkungan. Penelitian ini bertujuan merumuskan kadar BOD, Minyak dan Lemak di Permukiman Desa Bakau Besar Laut Kec. Sungai Pinyuh Kab. Mempawah Berdasarkan PP No. 82 Tahun 2001. 

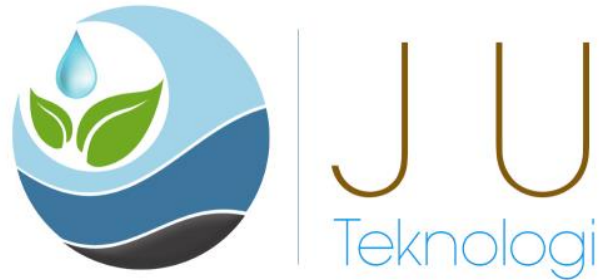
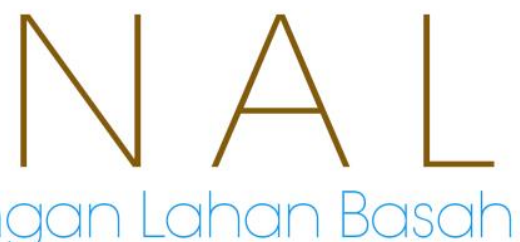

\section{METODOLOGI PENELITIAN}

Pengambilan sampel dilakukan dengan metode Grab Sampling untuk mengetahui kualitas BOD, Minyak dan Lemak (Alaerts, 1987). Lokasi pengambilan sampel air drainase pertanian diambil secara langsung untuk mengetahui kualitas air dan dilakukan pada beberapa titik yang disajikan pada Tabel 1 .

Tabel 1. Hasil Kualitas Air Drainase Pertanian

\begin{tabular}{|c|c|c|c|c|}
\hline \multirow{2}{*}{ Parameter } & \multirow{2}{*}{ satuan } & \multicolumn{2}{|c|}{ Radius (m) } & \multirow{2}{*}{ Standar } \\
\hline & & 700 & 1500 & \\
\hline BOD & $\mathrm{mg} / \mathrm{l}$ & 15 & 13 & $2 * 6 * * *$ \\
\hline $\begin{array}{c}\text { Minyak \& } \\
\text { Lemak }\end{array}$ & $\mathrm{mg} / \mathrm{l}$ & 0 & 0 & 1000 \\
\hline
\end{tabular}

Pengambilan sampel air drainase pertanian dimulai dari radius $700 \mathrm{~m}$ dan $1500 \mathrm{~m}$ dari lokasi tambak udang. Lokasi pengambilan sampel air drainase warga diambil secara langsung untuk mengetahui kualitas air dan dilakukan pada beberapa titik yang di sajikan pada Tabel 2.

Tabel 2. Hasil Kualitas Air Drainase Permukiman

\begin{tabular}{|c|c|c|c|c|}
\hline \multirow{2}{*}{ Parameter } & \multirow{2}{*}{ Satuan } & \multicolumn{2}{|c|}{ Radius (m) } & \multirow{2}{*}{ Standar } \\
\cline { 3 - 4 } & 500 & 1000 & \\
\hline BOD & $\mathrm{mg} / \mathrm{l}$ & 48 & 20 & 2 \\
\hline $\begin{array}{c}\text { Minyak \& } \\
\text { Lemak }\end{array}$ & $\mathrm{mg} / \mathrm{l}$ & 0,011 & 0,002 & 1000 \\
\hline
\end{tabular}

Sumber: Astanti, 2016

Pengambilan air sampel drainase permukiman dimulai dari radius $500 \mathrm{~m}$ dan $1000 \mathrm{~m}$ dari lokasi tambak. Hasil dari kualitas air yang diambil selanjutnya diuji di laboratorium dan dilakukan pengujian signifikasi melalui uji statistik dengan metode Mann Whitney.

\section{HASIL DAN PEMBAHASAN}

Gambar 1 memberikan gambaran kualitas air drainase di RW 3 dan RW 4 Desa Bakau Besar Laut, Kecamatan Sungai Pinyuh yang mempunyai luas wilayah $201 \mathrm{Ha}$ atau 2,01 km² . Dari hasil kualitas air drainase pertanian pada radius $700 \mathrm{~m}$ dan $1500 \mathrm{~m}$ (Tabel 1) BOD mengalami konsentrasi yang melebihi baku mutu lingkungan berdasarkan standar PP 82 tahun 2001.

Nilai BOD yang paling tinggi terdapat pada radius $700 \mathrm{~m}$, tingginya BOD pada radius tersebut dikarenakan adanya permukiman penduduk, aktivitas pertanian dan dekat dengan lokasi tambak udang yang menjadikan nilai BOD tinggi sehingga sulit untuk menguraikan kandungan organik dengan menggunakan bantuan mikroorganisme yang tumbuh secara alami. Hal ini yang membuat kandungan BOD pada radius $700 \mathrm{~m}$ dikarenakan tingginya konsentrasi BOD buangan tambak udang (Tabel 1) yang turut berkontribusi menyumbang tingginya konsentrasi BOD pada air drainase pertanian radius $700 \mathrm{~m}$.

Nilai kualitas air BOD pada radius 1500 $\mathrm{m}$ sebesar $13 \mathrm{mg} / \mathrm{l}$ menunjukkan konsentrasi BOD pada drainase pertanian mengalami penurunan dikarenakan drainase pada radius $1700 \mathrm{~m}$ cukup jauh dari faktor pencemar seperti tambak udang dan industri kopra serta adanya mikro organisme yang tumbuh secara alami yang mendegradasi bahan pencemar meskipun lambat. Faktor lain yang menyebabkan perbedaan konsentrasi adalah dekatnya drainase warga pada radius $1500 \mathrm{~m}$ dengan sungai yang memungkinkan terjadinya 

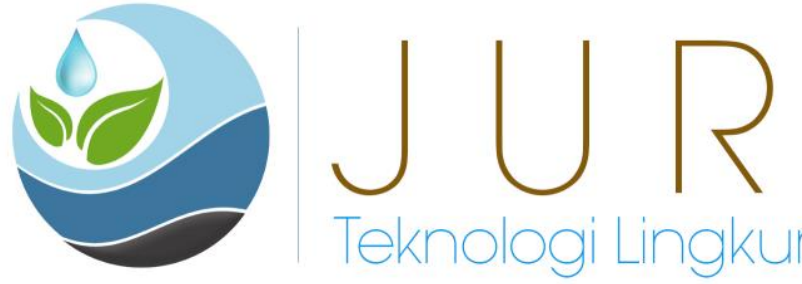

pengenceran saat pasang ataupun surut serta adanya vegetasi tanaman yang tumbuh secara alami dapat membantu bahan organik / pencemar terdegradasi dengan baik meskipun lambat (Bambang, 2006). Meskipun pada radius $1500 \mathrm{~km}$ konsentrasi BOD mengalami penurunan dari radius 700 $\mathrm{m}$, tetapi konsentrasi tersebut telah melewati standar baku mutu yang diizinkan oleh PP 82 tahun 2001. Hal ini membuktikan bahwa tidak ada perbedaan yang nyata antara radius $700 \mathrm{~m}$ dan 1500 $\mathrm{km}$.

Aktivitas masyarakat yang mencuci pakaian langsung disungai, memandikan ternak di sungai dan membuang sisa deterjen langsung ke tanah dapat berkontribusi langsung dalam meningkatkan nilai BOD. Tingginya nilai BOD pada air drainase pertanian ini dapat membentuk suatu zat pencemar seperti TSS (Total Suspended Solid), dalam jangka waktu yang cukup lama akan mengumpul pada permukaan tanah dan menyebabkan tersumbatnya pori - pori tanah sehingga tanah menjadi tidak subur (Sudir, 2014). Tingginya kandungan BOD terhadap tanaman dapat mengakibatkan tanaman rentan terhadap penyakit busuk batang dan daun pada tanaman padi. Hal ini terbukti pada hasil penelitian yang disajikan yaitu sebanyak $83,7 \%$ tanaman responden mengalami keluhan penyakit busuk batang dan daun. Hal ini dikarenakan tingginya kandungan BOD mengakibatkan tanaman tidak berfotosintesis dengan baik sehingga menyebabkan hasil padi kerdil dengan bulir - bulir gabah kecil (Sudir,2014).

Minyak dan lemak pada masing - masing radius sebesar $0 \mathrm{mg} / \mathrm{l}$. Hal ini dikarenakan akibat adanya limbah deterjen yang mampu menguraikan lemak. Sehingga tidak

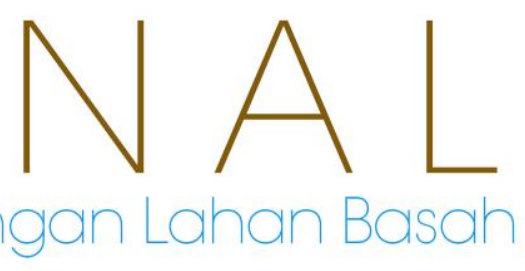

terdapatnya limbah minyak dan lemak didalam perairan tersebut (Ginting, 2007).

Hasil konsentrasi BOD pada air drainase pertanian masing - masing radius selanjutnya diuji dengan menggunakan metode Mann Whitney untuk mengetahui kedua hubungan radius tersebut. Hasil mean rank atau rata - rata peringkat tiap radius menunjukkan pada radius $700 \mathrm{~m}$ nilai mean rank sebesar 6,92 lebih tinggi dari pada radius $1500 \mathrm{~m}$, yaitu sebesar 6,08. Hal ini membuktikan konsentrasi tertinggi dari masing - masing radius berada pada radius $700 \mathrm{~m}$ yang bertpotensi mendapatkan beban pencemar yang paling tinggi. Selanjutnya untuk mengetahui perbedaan antara dua radius bermakna secara statistik, dilakukan uji signifikan yang hasilnya menunjukkan nilai $U$ sebesar 15 dan nilai $W$ sebesar 36,5. Apabila dikonversikan ke nilai $Z$ maka besarnya -4166. Nilai sig atau $p$ Value sebesar 0,677>0,05. Apabila nilai $\mathrm{p}$ value > batas kritis 0,05 maka tidak terdapat perbedaan bermakna antara dua radius. Hal ini menjelaskan kedua radius telah dicemari oleh faktor - faktor pencemar yang bersumber dari industri, tambak, pertanian dan permukiman, sehingga nilai BOD pada kedua radius melewati standar PP 82 tahun 2001.

Konsentrasi BOD pada drainase permukiman warga juga mengalami penurunan dikarenakan BOD yang diuji telah melewati baku mutu lingkungan dalam standar PP 82 tahun 2001 (Tabel 2). Hal ini disebabkan oleh drainase dengan fungsi utama sebagai saluran alami yang dapat mengurangi genangan atau banjir (Ginting, 2007), tetapi digunakan oleh masyarakat di RW 3 dan 

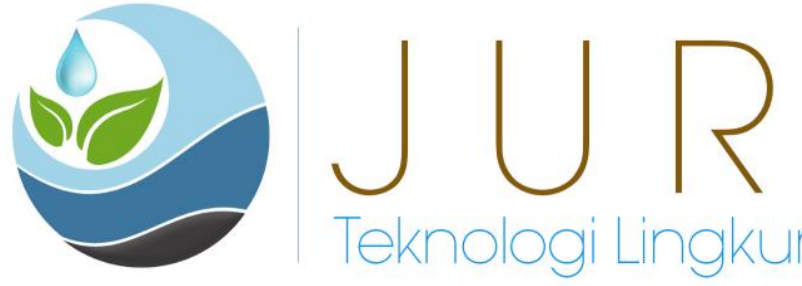

RW 4 untuk aktivitas yang beragam, yaitu sumber air untuk mandi/cuci dan memandikan ternak. Aktivitas memandikan ternak meningkatkan pengaruh penurunan kualitas air di saluran drainase ini dan berdampak terhadap kesehatan masyarakat. Hal ini dikarenakan penggunaan air drainase tersebut tidak sesuai dengan peruntukkannya sehingga sudah tercemar dan juga dapat mempengaruhi kualitas air drainase untuk pertanian.

Hasil kualitas air drainase warga pada masing - masing radius selanjutnya di uji dengan menggunakan metode Mann Whitney untuk mengetahui kedua hubungan radius tersebut. Hasil rank uji Mann Whitney menunjukkan mean rank atau rata - rata peringkat tiap radius. Yaitu pada radius $<500 \mathrm{~m}$ peringkatnya 6,58 lebih tinggi dari pada rata - rata peringkat kedua, yaitu 6,42. Hal ini membuktikan konsentrasi tertinggi dari masing - masing radius berada pada radius $<500 \mathrm{~m}$. Hal ini dikarenakan radius $<500 \mathrm{~m}$ dekat dengan faktor - faktor pencemar yang dapat berkontribusi sebagai bahan pencemar. Selanjutnya untuk mengetahui perbedaan antara dua radius bermakna secara statistik, dilakukan uji signifikan yang hasilnya menunjukkan nilai U sebesar 17,5 dan nilai $W$ sebesar 38,5. Apabila dikonversikan ke nilai $\mathrm{Z}$ maka besarnya -0,80. Nilai sig atau $p$ Value sebesar 0,936 > 0,05. Apabila nilai $\mathrm{p}$ value $>$ batas kritis 0,05 maka tidak terdapat perbedaan bermakna antara dua radius.

Kandungan BOD pada masing - masing radius menunjukan konsentrasi sebesar 48

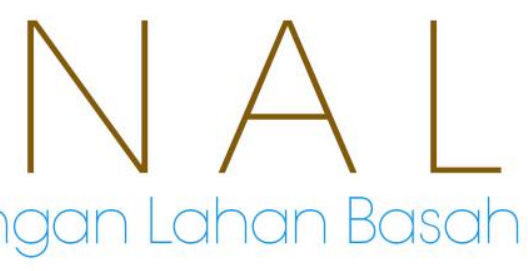

mg/l dan 20 mg/l/. Kandungan BOD pada masing - masing radius telah melewati baku mutu BOD sesuai PP 82 tahun 2001 kelas 1 yang diperbolehkan yaitu < 2 $\mathrm{mg} / \mathrm{l}$. Nilai BOD yang paling tinggi terdapat pada radius $500 \mathrm{~m}$. hal ini dikarenakan adanya permukiman penduduk, aktivitas pertanian dan dekat dengan lokasi tambak udang yang menjadikan nilai BOD tinggi.

Faktor lain yang cukup berkontribusi adalah buangan limbah dari lokasi tambak yang mengandung banyak nutrien zat organik. Hal ini terbukti dari tingginya nilai BOD buangan tambak udang yang menambah akumulasi bahan pencemar yang meningkatkan konsentrasi BOD. Hal ini menyulitkan untuk menguraikan kandungan organik dengan menggunakan bantuan oksigen, dikarenakan terlalu banyak nutrien serta beban pencemar yang berkontribusi ke dalam saluran air drainase warga. Nilai BOD pada radius 1 $\mathrm{km}$ sebesar $20 \mathrm{mg} / \mathrm{l}$ menunjukkan konsentrasi BOD pada drainase warga mengalami penurunan dikarenakan drainase pada radius $1 \mathrm{~km}$ cukup jauh dari faktor pencemar seperti tambak udang yang memiliki konsentrasi BOD yang tinggi. Faktor lain yang menyebabkan perbedaan konsentrasi adalah dekatnya drainase warga pada radius $1 \mathrm{~km}$ dengan sungai yang memungkinkan terjadinya pengenceran saat pasang ataupun surut. Meskipun pada radius $1 \mathrm{~km}$ konsentrasi BOD lebih kecih dari radius $500 \mathrm{~m}$, tetapi konsentrasi tersebut telah melewati standar baku mutu yang diizinkan oleh PP 

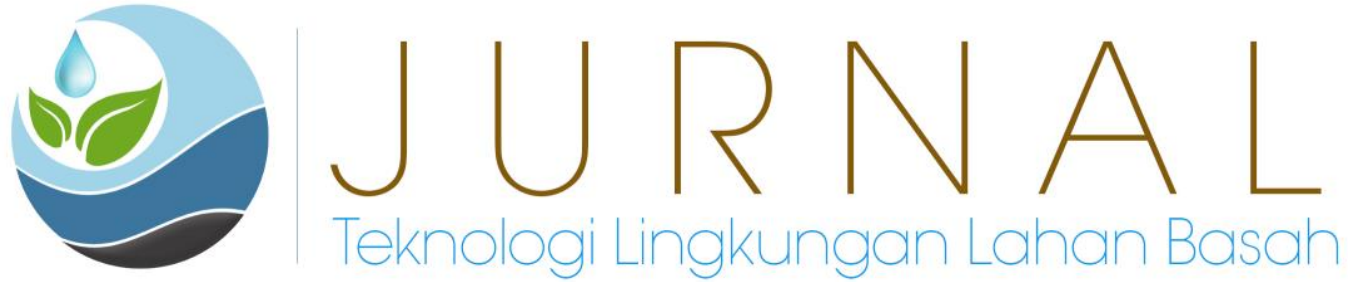

82 tahun 2001. Hal ini membuktikan bahwa tidak ada perbedaan yang nyata antara radius $500 \mathrm{~m}$ dan $1 \mathrm{~km}$. Aktivitas masyrakat yang mencuci pakaian langsung disungai, memandikan ternak disungai dan membuang sisa deterjen langsung ke tanah dapat berkontribusi langsung dalam meningkatkan nilai BOD. Tingginya konsentrasi BOD pada air drainase warga yang telah diuji berpotensi berdampak bagi kesehatan manusia diantaranya dapat terserang penyakit kulit, saluran pernapasan, diare dan menurunkan daya tahan tubuh. Hal ini dibuktikan dari hasil penelitian sebanyak $42 \%$ masyarakat mengalami keluhan penyakit diare dan $22 \%$ mengalami keluhan penyakit alergi yang disebabkan masyarakat menggunakan air sumur dangkal (gali), air sumur dalam (bor) dan sungai yang berpotensi dapat tercemar oleh air drainase tersebut.

Selanjutnya Minyak dan lemak pada masing - masing radius sebesar $0 \mathrm{mg} / \mathrm{l}$. Hal ini menunjukkan tidak terdapatnya limbah minyak dan lemak didalam perairan tersebut. Hal ini dikarenakan lemak dapat mengendap menjadi lumpur dan mengendap yang sulit diuraikan (Ginting, 2007). Kedua radius drainase warga yang seharusnya diperuntukan sebagai saluran air limbah juga digunakan untuk MCK yang menjadikan konsentrasi BOD pada air drainase warga pada masing - masing radius telah melewati standar baku mutu PP 82 tahun 2001.

Salah satu faktor penentu tingginya kadar BOD di permukiman diantaranya adalah kualitas air drainase. Masyarakat di RW 3 dan RW 4 Desa Bakau Besar Laut memfungsikan drainase kawasan sebagai sumber air untuk MCK sehingga tidak sesuai dengan peruntukkannya dan menjadikan saluran drainase tersebut menjadi tercemar (Tabel 1 dan 2). Lokasi permukiman yang berdekatan dengan industri akan mempengaruhi penurunan sanitasi dan drainase di kawasan sekitar karena drainase dalam kondisi yang tidak berfungsi dengan baik. Hal ini terjadi karena adanya kegiatan ekonomi berupa RPH babi yang berada di lingkungan ini yang membuang limbahnya ke saluran air di sekitar permukiman tersebut. Penelitian serupa oleh Cahyadi (2014) mengenai analisis terhadap kualitas air sumur dangkal yang dipengaruhi oleh berbagai aktivitas sekitarnya diperoleh temuan potensi parameter yang ikut mencemari kualitas air sumur, yang menujukkan beberapa parameter yang sama seperti: Amoniak, Zat Organik dan warna yang melebihi standar Baku Mutu Lingkungan. 
Jurnal Teknologi Lingkungan Lahan Basah, Vol. 01, No. 2, 2018: 011 - 020
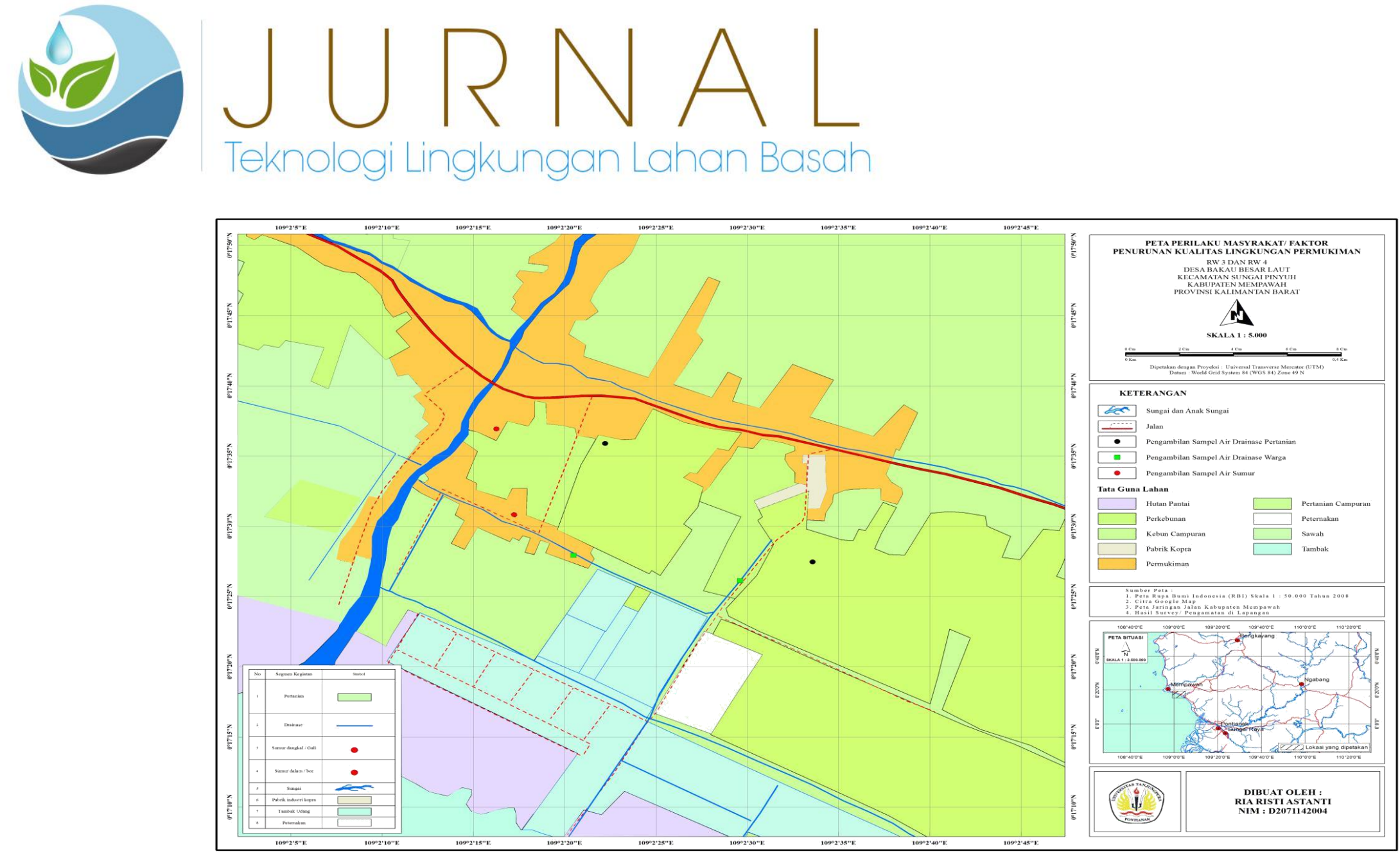

Gambar 1. Parameter hasil uji Kualitas Lingkungan Permukiman di RW 3 dan RW 4 Desa Bakau Besar Laut Kec. Sungai Pinyuh Sumber: Data primer 

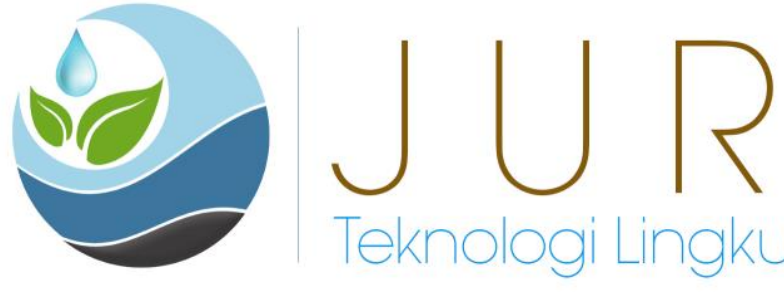

Keterangan Gambar 1 menunjukkan saluran drainase warga yang berubah fungsi dan tidak sesuai peruntukkannya. Drainase permukiman ini telah dijadikan masyarakat sebagai sumber air untuk MCK dan muara untuk tempat pembuangan limbah baik secara langsung maupun tidak langsung. Hal ini menjadikan kualitas air drainase mengalami penurunan sehingga saluran ini tidak dapat bekerja secara optimal untuk menampung dan mengalirkan air hujan. Kondisi ini juga menjadikan saluran tidak dapat menampung limpasan dari air permukaan akibat hujan untuk mencegah terjadinya genangan dan banjir. Sumber air berupa sumur dangkal/gali masyarakat di Desa Bakau Besar Laut dijadikan sebagai sumber air untuk MCK dan sumber air minum dan masak.

Faktor yang berperan penting mempengaruhi kondisi permukiman adalah pola hidup dan kegiatan masyarakat di sekitar permukiman tersebut (Thompson \& Newmark, 1977). Uji di laboratorium diperoleh hasil kualitas air sumur tersebut hanya layak untuk mandi tetapi tidak layak sebagai sumber air minum dan masak. Mengkonsumsi air sumur dengan kualitas air yang tidak sesuai dapat mengganggu kesehatan bagi pemakainya (Saudin, 2005). Banyaknya keluhan dari masyarakat mengenai kesehatan dapat menandakan bahwa permukiman tersebut mengalami penurunan yang disebabkan oleh beberapa faktor salah satunya adalah yang bersumber dari air baku yang dikonsumsi (Mutakin, 2008). Dari hasil observasi lapangan, air sumur tanah dalam / bor juga dimanfaatkan masyarakat sebagai sumber air baku / air bersih untuk memasak dan konsumsi. Hal ini dikarenakan kawasan ini tidak memiliki instalasi air bersih dari PDAM setempat. Kondisi yang sama juga terlihat pada aliran sungai yang digunakan

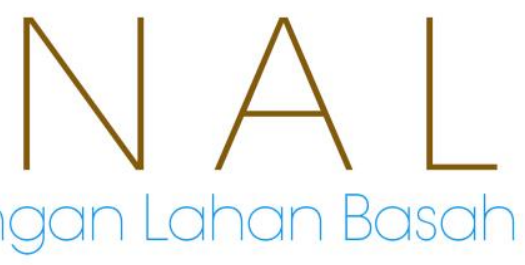

oleh masyarakat sebagai sumber air baku / bersih dan MCK. Sungai ini juga dijadikan masyarakat sebagai lokasi pembuangan sampah secara langsung maupun tidak langsung seperti limbah sisa pertanian, memandikan ternak dan mencuci alat keperluan masak.

Aktivitas-aktivitas masyarakat ini mengakibatkan penurunan kualitas air sungai tersebut yang apabila dikonsumsi dapat berdampak kepada kesehatan masyarakat atau digunakan sebagai sumber air irigasi akan berpengaruh pada kualitas tanaman di area pertanian sekitar (Sumaatmadja, 2010). Selanjutnya faktor yang dapat menurunkan kualitas lingkungan permukiman adalah aktivitas pabrik industri yang melakukan pembuangan limbah tanpa melakukan pengolahan terlebih dahulu dan dilakukan secara terus menerus. Dari hasil penelitian Astianti (2014), ditemukan bahwa beberapa parameter hasil buangan tambak seperti Amoniak, BOD dan COD telah melewati standar baku mutu yang disyaratkan dalam Keputusan Menteri LH nomor 26 tahun 2004 tentang standar buangan budidaya tambak udang. Aktivitas dari tambak udang yang membuang limbahnya tanpa melakukan pengolahan terlebih dahulu telah berdampak terhadap lingkungan alam dan lingkungan permukiman di Desa Bakau Besar Laut, khususnya yang berada di radius $500 \mathrm{~m}$ dan $1000 \mathrm{~m}$ dari lokasi tambak udang tersebut. Aktivitas lain yang dapat berkontribusi sebagai faktor pencemar dan penurunan kualitas permukiman adalah peternakan dengan membuang limbah ternaknya secara sembarangan dan tidak terkonsep dengan baik (Soemirat, 1994). Hal ini dapat menyebabkan sumber air yang digunakan 

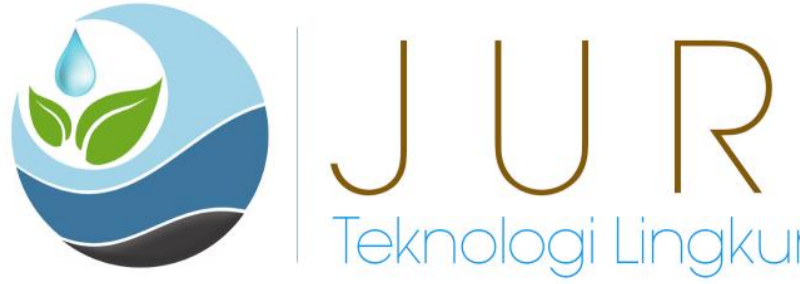

oleh warga menjadi tercemar. Keseluruhan segmen yang ditunjukkan pada Gambar 2adalah faktor penentu kadar pencemaran air di permukiman di Desa Bakau besar Laut RW 3 dan RW 4. Kondisi ini sejalan dengan penelitian yang dilakukan oleh Saudin (2005) yang menyimpulkan bahwa faktor pendukung yang dapat mempengaruhi kualitas suatu permukiman salah satunya adalah kualitas air yang masyarakat gunakan serta sanitasi lingkungan dengan kondisi kesehatan masyarakat yang bermukim di permukiman tersebut.

Rekomendasi yang diberikan untuk meningkatkan kualitas permukiman di RW 3 dan RW 4 Desa Bakau Besar Laut Kecamatan Sungai Pinyuh agar kualitas air drainase dapat terjaga dengan baik dan sesuai peruntukkannya diantaranya; membangun PAB (Pengolahan Air Bersih) yang bersumber dari sungai Bakau Besar Laut, menyiapakan tempat sampah sesuai dengan kriteria sampah yaitu sampah organik dan anorganik, membangun IPAL (Instalasi Pengolahan Air Limbah) untuk pelaku usaha industri dan membangun IPB (Instalasi Pengolahan Biogas) bagi pelaku industri ternak.

\section{KESIMPULAN}

Kesimpulan yang diperoleh dalam penelitian terhadap Kualitas lingkungan permukiman di Desa Bakau Besar Laut Kecamatan Sungai Pinyuh adalah:

- Konsentrasi BOD pada masing - masing drainase telah melewati standar baku mutu PP 82 tahun 2001

- Konsentrasi Minyak dan Lemak tidak melewati standar baku mutu PP 82 tahun 2001

- Berdasarkan hasil uji statistik Mann whitney didapatkan kadar BOD, Minyak dan Lemak diantaranya radius $700 \mathrm{~m}>$
$1700 \mathrm{~m}$ (drainase pertanian) dengan nilai sig $0,677>0,05 ; 500 \mathrm{~m}>1500 \mathrm{~m}$ (drainase warga) dengan nilai sig 0,936 $>0,05$

- Rekomendasi berupa pengolahan air bersih (PAM) dengan intake yang berasal dari sungai Bakau Besar Laut, melakukan pemisahan sampah sesuai dengan karakteristik limbahnya yaitu organik, anorganik dan B3, mendirikan IPAL (Instalasi Pengolahan Air Limbah) untuk industri tambak udang dan pengolahan kopra serta mendirikan pengolahan Biogas berbahan baku limbah ternak sebagai sumber bahan bakar dan pupuk kompos organik yang dapat dimanfaatkan kembali oleh masyarakat.

\section{Daftar Pustaka}

Achmad, R. 2004. Kimia Lingkungan. Andi Offset: Yogyakarta

Alaerts, G. 1987. Metode Penelitian Air. Usaha Nasional: Surabaya

Astanti, Ria. 2014 Pengaruh Penambahan Probiotik terhadap Buangan Budidaya Udang Tambak. Skripsi Program Studi Teknik Lingkungan Fakultas Teknik Universitas Tanjungpura: Pontianak.

Astanti, Ria. 2016. Kualitas Lingkungan Permukiman di Desa Bakau Besar Laut. Tesis pada Program Studi Teknik SipilFakultas Teknik Universitas Tanjungpura: Pontianak

Prasetyo, Bambang. 2006. Metode Penelitian Kuantitatif : Teori dan Aplikasi. Raja Grafindo Persada : Jakarta.

Cahyadi, Didi. 2014. Pengaruh sistem sanitasi terhadap kualitas air sumur 

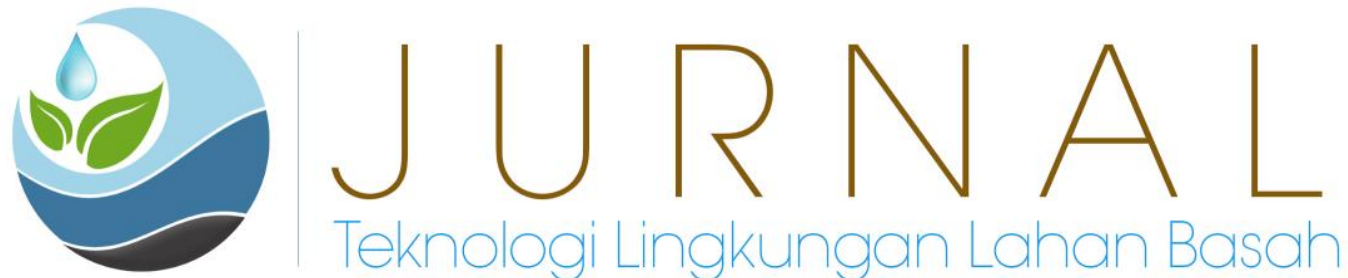

dangkal pada perumahan tipe kecil. Skripsi pada Program Studi Teknik Lingkungan Universitas Surabaya: Surabaya

Departemen Permukiman dan Prasarana Wilayah. 2003. Pedoman Pengelolaan Persampahan Perkotaan Bagi Pelaku Pelaksana. Direktorat Jenderal Tata Perkotaan dan Tata Pedesaan: Jakarta

Faiz, Sabina. 2009. Strategy to Reduce Eclusion Among Population Living in Urban Slum Settlements in Bangladesh. Jams P. Grant School of Public Health BRAC University: Dhaka

Fitria, Niken. 2014. Identifikasi Karakteristik Lingkungan Kumuh di Kelurahan Kapuk, Jakarta Barat. Program Studi Perencanaan Wilayah dan Kota Fakultas Teknik Sipil dan Perencanaan Universitas Sepuluh November: Surabaya

Ginting, P. 2007. Sistem Pengelolaan Lingkungan dan Limbah Industri. Bandung: Yrama Widya

Hendrawan, Diana. 2005. Kualitas Air Sungai Dan Situ Di DKI Jakarta. Makara Teknologi, Vol. 9 (1) April $2005: 13$ - 19.

Mutakin, Awan. 2008. Pendidikan Geografi Perilaku Keragaman Perilaku Kelingkungan. FPIPS Universitas Pendidika. Indonesia: Bandung

Newmark, P.A ; Thompson, . 1997. Self, Space, and Shelter. Harper and Row Publisher: New York

Palar, H. 2008. Pencemaran dan Toksikologi Logam Berat. Rineka Cipta: Jakarta.
Richards, Robin. 2007. Measuring Quality Of Life In Informal Settlements In South Africa. Social Indicators Research, Vol.81(2), PP $375-388$

Saudin. 2005. Hubungan Kualitas Air Sumur dengan Kejadian Diare di Solo. Skripsi pada Program Studi PWK Universitas Diponegoro: Semarang

Slamet. 1984. Pencemaran Air. Karya Anda: Surabaya

Sudir. 2014. Interaksi \& Motivasi Belajar Mengajar. Jakarta: Raja Grafindo Persada

Sumaatmadja, N. 2010. Manusia dalam Konteks Sosial, Budaya dan Lingkungan Hidup. CV Alfabeta: Bandung 